\title{
Article/Artigo
}

\section{Serological survey for Chagas disease in the rural areas of Manaus, Coari, and Tefé in the Western Brazilian Amazon}

\author{
Inquérito sorológico para doença de Chagas em áreas rurais de Manaus, Coari e Tefé na \\ Amazônia Ocidental
}
Belisa Maria Lopes Magalhães ${ }^{1}$, Leíla Ines Aguiar Raposo Câmara Coelho ${ }^{2,3}$, Marcel Gonçalves Maciel', João Marcos Benfica Barbosa Ferreira ${ }^{3}$, Eufrozina Setsu Umezawa ${ }^{4}$, José Rodrigues Coura ${ }^{5}$, Jorge Augusto de Oliveira Guerra $^{1,2}$ and Maria das Graças Vale Barbosa ${ }^{1,2,6}$

\begin{abstract}
Introduction: Deforestation, uncontrolled forest, human population migration from endemic areas, and the large number of reservoirs and wild vectors naturally infected by Trypanosoma cruzi promote the endemicity of Chagas disease in the Amazon region. Methods: We conducted an initial serological survey (ELISA) in a sample of 1,263 persons; 1,095 (86.7\%) were natives of the State of Amazonas, 666 (52.7\%) were male, and 948 (75.1\%) were over 20 years old. Serum samples that were found to be reactive, indeterminate, or inconclusive by indirect immunofluorescence (IFI) or positive with low titer by IFA were tested by Western blot (WB). Serologically confirmed patients (WB) were evaluated in terms of epidemiological, clinical, ECG, and echocardiography characteristics. Results: Fifteen patients had serologically confirmed T. cruzi infection, and 12 of them were autochthonous to the state of Amazonas, for an overall seroprevalence of $1.2 \%$ and $0.9 \%$ for the state of Amazonas. Five of the 15 cases were males, and the average age was 47 years old; most were farmers with low education. One patient who was not autochthonous, having originated from Alagoas, showed right bundle branch block, bundle branch block, and anterosuperior left ventricular systolic dysfunction with an ejection fraction of $54 \%$. Conclusions: The results of this study ratify the importance of monitoring CD cases in Amazonia, particularly in the state of Amazonas.
\end{abstract}

Keywords: Chagas Disease. Serological Survey. Brazilian Amazon.

\section{RESUMO}

Introdução: Na Amazônia, o desmatamento desordenado da floresta, as migrações populacionais humanas de áreas endêmicas e o grande número de reservatórios e vetores silvestres naturalmente infectados por Trypanosoma cruzi, favorece a endemicidade da doença de Chagas nessa região. Métodos: Foi realizado um inquérito sorológico inicial por ensaio imunoenzimático (ELISA), em uma amostra de 1.263 pessoas, $1.095(86,7 \%)$ as quais eram autóctones do Estado do Amazonas, $666(52,7 \%)$ do sexo masculino, $948(75,1 \%)$ com idade superior a 20 anos. As amostras de soro reativas, indeterminadas ou inconclusivas por imunofluorescência indireta (IFI) positivas ou com baixo título na IFI foram submetidas ao Western blot (WB). Os pacientes com sorologia confirmada (WB) foram avaliados do ponto de vista epidemiológico, clínico, eletro e ecocardiográfico. Resultados: Quinze pacientes tiveram sorologia confirmada para infecção por T. cruzi, 12 dos quais autóctones do Estado do Amazonas, com uma prevalência sorológica geral de $1,2 \%$ e de $0,9 \%$ para o Estado do Amazonas. Entre os 15 casos com sorologia positiva, cinco eram do sexo masculino, média de idade de 47 anos, baixa escolaridade e a maioria agricultores. Um paciente não autoctone, procedente de Alagoas, apresentou bloqueio de ramo direito, bloqueio divisional ântero-superior e disfunção sistólica ventricular esquerda com fração de ejeção de 54\%. Conclusões: O resultado deste estudo reforça a importância do monitoramento de casos da doença de Chagas na Amazônia, em especial no Amazonas.

Palavras-chaves: Doença de Chagas. Inquérito sorológico. Amazônia brasileira.

1. Escola Superior de Ciências da Saude, Programa de Pós-graduação em Medicina Tropical, Universidade do Estado do Amazonas, Manaus, AM. 2. Gerência de Entolomogia e Leishmaniose, Fundação de Medicina Tropical Heitor Vieira Dourado, Manaus, AM. 3. Faculdade de Farmácia e Faculdade de Medicina, Universidade Federal do Amazonas, Manaus, AM. 4. Laboratório de Doenças Parasitárias, Instituto de Medicina Tropical de São Paulo, São Paulo, SP. 5. Laboratório de Doenças Parasitárias, Fundação Oswaldo Cruz, Rio de Janeiro, RJ. 6. Departamento de Biologia, Universidade Nilton Lins, Manaus, AM.

Address to: Dra. Maria das Graças Vale Barbosa. Gerência de Entomologia/FMT. Av. Pedro Teixeira 25, Dom Pedro, 69040-000 Manaus, AM, Brasil.

Phone: 5592 2127-3433

e-mail: gbarbosa@fmt.am.gov.br

Received in $11 / 02 / 2011$

Accepted in 17/06/2011

\section{INTRODUCTION}

The Brazilian Amazon is no longer considered free from human Chagas disease (CD) due to the occurrence of acute autochthonous cases ${ }^{1-6}$, initially reported in Belém do Pará ${ }^{1}$, followed by acute and chronic cases in humans in other areas ${ }^{1-6}$. Among the contributing factors that helped its spread as a human endemic disease $\mathrm{e}^{7-10}$ were the human population migrations from endemic areas to the Amazon ${ }^{10-11}$, the disordered deforestation of the Amazon rainforest, and the increasing proximity between people and the reservoir host and vectors naturally infected by Trypanosoma cruzi, turning the disease into an endemic $c^{2-3,9-11}$.

In the State of Amazonas, $\mathrm{CD}$ cases have been reported since $1977^{12}$, starting with the first autochthonous case described in São Paulo de Olivença in $1979^{13}$ and vectors described since 1919 with Matta's ${ }^{14}$ description of the Rhodnius brethesi. In 1971, the occurrence of T. cruzi from naturally infected triatomines, which were implicated in the transmission of the disease, was reported in the City of Manaus ${ }^{15}$.Sincethen, therehavebeensuspectedorconfirmed acute and chronic $\mathrm{CD}$ cases in this state, occasionally ${ }^{5-6,16-18}$.

The Serologic National Inquiry carried out from 1975 to 1980 indicated a prevalence of $1.9 \%$ in the State of Amazonas ${ }^{19}$. However, there were records of $6.8 \%$ and $4.6 \%$ prevalence in Barcelos and Novo Airão, respectively $y^{6,16}$. Regardless of such numbers, the infection dynamics has not been well established yet, as there are no records of the domiciliation of vectors. Currently, the vast majority of cases in the area are related to oral route transmission and associated with the ingestion of palm tree fruit juice, besides the occurrence of an outbreak in the acute phase of the disease $e^{4,17,20}$. The detection of occasional clinical CD cases in this area provides data that allow the implementation of actions against its dissemination in the area ${ }^{10-11}$. In this context, the purpose of this work was to estimate the infection rate of Chagas disease in its chronic form among inhabitants of rural areas in the Cities of Manaus, Coari, and Tefé, in the State of Amazonas. 


\section{METHODS}

\section{Location and characteristics of the area}

The study was undertaken in rural areas in previously selected cities where acute autochthonous cases of $\mathrm{CD}$ have been registered. In Manaus, data collection was done in the Tarumã-Mirim settlement located on Highway BR 174, km 21 (2० 48' 18,41”' S, 600 05' $\left.04,56^{\prime \prime} \mathrm{O}\right)$, which is accessed by land. In Coari (4 $04^{\prime} 32,61^{\prime \prime} \mathrm{S}, 63^{\circ}$ $\left.066^{\prime} 37,80^{\prime \prime}\right)$, the study was carried out in the communities of Costa do Juçara, Mato Grosso, Itapéua, and Saubinha. In Tefé ( $3^{\circ} 19^{\prime}$ 47,61”S; $\left.64^{\circ} 43^{\prime} 57,94^{\prime \prime} \mathrm{)}\right)$, the study was conducted in the communities of Bacuri, Nova Jerusalém, Turé, São Benedito, Bom Jesus, Maranata, Agrovila, and São Francisco do Canindé. In Coari and Tefé, access is made exclusively by boat (Figure 1).

\section{Studied population and type of study}

This was a sectional and descriptive study of the local population in the selected communities, which willingly agreed to participate, allowing visits to their dwellings. All age groups were included, and visits were conducted (up to three attempts) at different times from September 2007 to November 2008.

A query about epidemiological, socioeconomic, and sanitary information, as well as other clinical data, was applied to gather epidemiological variables. Information about the surrounding area of the dwellings was also gathered, including population habits, which were used as variables to obtain more references in the discussion of the mechanisms of infection. During this query, triatomines from the medically relevant genuses, Triatoma, Panstrongylus, and Rhodnius, were presented to the inhabitants with the purpose of evaluating their capability to recognize them.

\section{Laboratorial proceedings}

A $5 \mathrm{ml}$ blood sample was collected by venous puncture and centrifuged; its serum portion was separated. Afterwards, the blood sample was placed in Eppendorf tubes and frozen at $-20^{\circ} \mathrm{C}$ for serology at the Fundação de Medicina Tropical Dr. Heitor Vieira Dourado, Manaus, Amazonas, a tertiary national reference health unit designed to handle tropical and infectious disease cases.

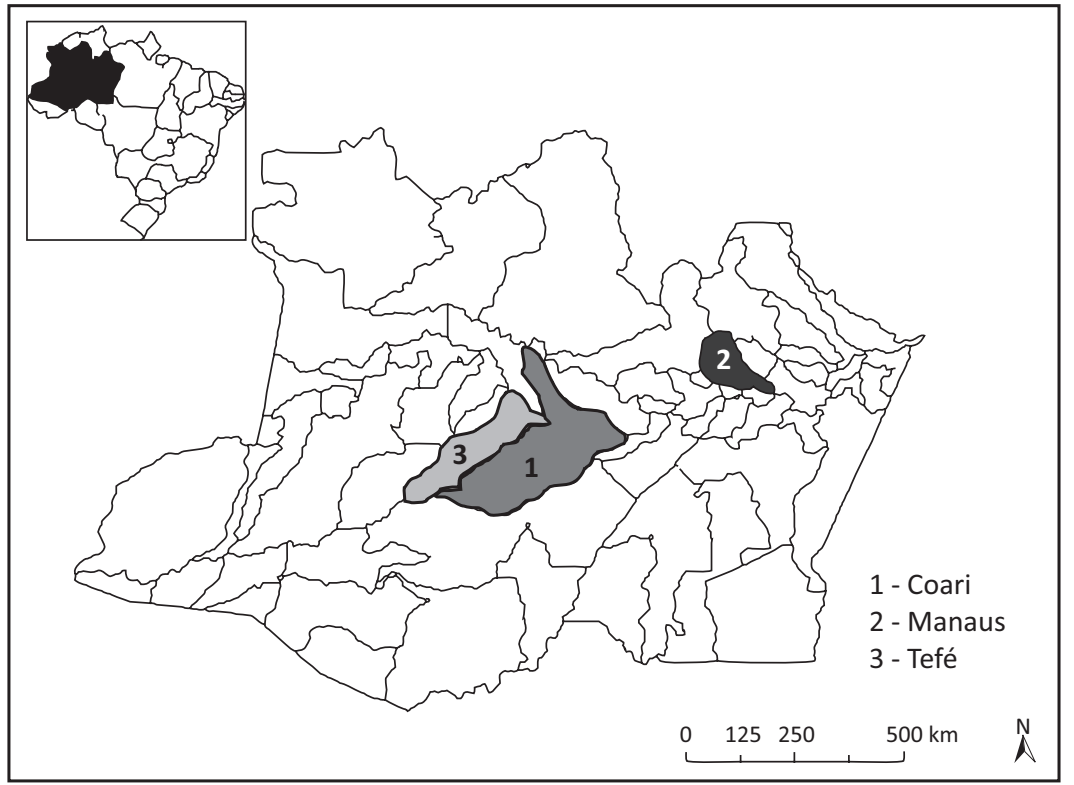

FIGURE 1 - Map of the State of Amazonas with emphasis on the three areas of study.
All samples were submitted to immunoenzymatic assay (ELISA) for qualitative analysis of IgG anti-T. cruzi antibodies in human serum. The assay procedure was automated and performed using ETI-Max 3000@ version 1.70.1. After this stage, the samples classified as reactive, as well as those that showed inconclusive or undetermined results, were submitted to indirect immunofluorescence antibody test (IFI) at 1:40 and 1:80 dilutions. The reactive and the low-titer samples on the IFI tests were analyzed by Western blot (WB), which is the confirmatory test for IgG anti-T. cruzi $i^{21-22}$ antibodies.

The antigens used in the serologic reactions by the ELISA and IFI techniques were obtained from the culture of the Y strain of T. cruzi in LIT medium. The human anti-IgG conjugates used in the ELISA technique were acquired from Ômega ${ }^{\circledR}(\operatorname{lot} 7015731)$ and those in the IFI test from Wama ${ }^{\circledR}$ (lot 802004$)$. The WB experiments were performed at the Universidade de São Paulo (USP) laboratory in accordance with the method standardized by Umezawa et al..$^{22}$ The ELISA reactions were measured by spectrophotometry $(450 \mathrm{~nm})$ using the ETI-Max 3000® version 1.70.1, and the IFI reactions were analyzed using epifluorescence (320-340nm) microscopy (Laica®).

Individuals who presented serologic reactivity in the Western blot technique ${ }^{22-23}$ were considered as chagasic infection cases.

\section{Clinical aspects}

All the chagasic infection cases were evaluated by anamnesis and physical examination to gather all information about manifestations (signs and symptoms) related to the cardiovascular and digestive systems, in accordance with a standard questionnaire. Furthermore, other tests were conducted, such as an electrocardiogram (D1, D2, D3, aVR, aVL and aVF, V1 to V6) and echocardiogram (standard and conventional cut planes) ${ }^{24-25}$.

\section{Statistical methods}

The tabulations and the statistical analysis were conducted using SPSS $\AA$ version 16.0 for Windows ${ }^{\circledR}$. The correlation between chagasic infection and sociodemographic and behavioral factors was tested by Chisquare test, with Yates' correction or Fisher's exact test when applicable. The prevalence and the confidence interval at $95 \%$ were calculated by bivariate analysis to estimate the degree of correlation between chagasic infection and the potential correlated factors.

\section{Ethical considerations}

The present study was approved by the Ethics and Research Committee of the Fundação de Medicina Tropical Dr Heitor Vieira Dourado (authorization number 1.836), and a Free and Clarified Consent Term was signed by the participants.

\section{RESULTS}

\section{Socio-epidemiological profile description}

Of the 1,263 subjects interviewed, 545 (43.2\%) were from Manaus rural areas, 399 (31.6\%) from Coari, and 319 (25.2\%) from Tefé. Moreover, 666 (52.7\%) were male, $948(75.1 \%)$ were over the age of 20 years, 662 (52.4\%) were farmers, 1,097 (86.8\%) were from the state of Amazonas, and 789 (62.4\%) were illiterate. Regarding the social environmental aspect, 1,125 (89.0\%) lived in wooden houses, of which 743 (58.8\%) had an asbestos roof; 691 (54.7\%) did not consume 
treated water, and 1,132 (89.6\%) had electricity. With regard to the variables that may introduce humans into the transmission cycle of T. cruzi, our data showed that 934 (73.9\%) of the interviewed people had palm trees in the surroundings of their houses, $982(77.8 \%)$ had domesticated animals, 869 (68.8\%) did not recognize any of the kissing bugs species that were shown to them during the visit, $1,099(87 \%)$ consumed palm tree fruit juice, and 962 (76.1\%) consumed sylvatic animal meat (hunt) (Table 1).

\section{Serologies}

Of the 1,263 samples, 24 (1.9\%) were reactive, and $10(0.8 \%)$ were inconclusive in the ELISA test. These 34 samples were submitted to IFI, in which 19 (1.5\%) were seropositive with titers between $1: 40$ and $1: 80^{21}$. Of the 19 samples submitted to WB test, 15 (1.2\%) were reactive (Figure 2). Fifteen cases were considered reactive for Trypanosoma cruzi infection, with a general prevalence of $1.2 \%$ (95\% CI: 0.34-2.22), of which 12 were autochthonous to the state of Amazonas, generating a prevalence of $0.9 \%$ for autochthonous cases in that state. The prevalence rates detected in Manaus, Coari, and Tefe were $1.2 \%, 0.5 \%$, and $1.9 \%$, respectively. Among the 15 diagnosed cases, the average age was 48 years ( $16-85$ years). Thirteen were male, including a 16-year-old and a 22-year-old; 9 (60\%) were adults aged over 40 years. Twelve were born in the State of Amazonas, 11 were

\begin{tabular}{|c|c|c|c|c|c|c|c|c|c|}
\hline \multirow[b]{2}{*}{ Category } & \multirow[t]{2}{*}{ Subcategory } & \multicolumn{2}{|c|}{$\begin{array}{l}\text { Coari } \\
\mathrm{n}=399\end{array}$} & \multicolumn{2}{|c|}{$\begin{array}{c}\text { Manaus } \\
\mathrm{n}=545\end{array}$} & \multicolumn{2}{|c|}{$\begin{array}{c}\text { Tefé } \\
n=319\end{array}$} & \multicolumn{2}{|c|}{$\begin{array}{c}\text { Total } \\
n=1,263\end{array}$} \\
\hline & & $\mathrm{n}$ & $\%$ & $\mathrm{n}$ & $\%$ & $\mathrm{n}$ & $\%$ & $\mathrm{n}$ & $\%$ \\
\hline \multirow[t]{2}{*}{ Gender } & male & 201 & 50.4 & 300 & 55.0 & 165 & 51.7 & 666 & 52.7 \\
\hline & female & 198 & 49.6 & 245 & 45.0 & 154 & 48.3 & 597 & 47.3 \\
\hline \multirow[t]{4}{*}{ Age (years) } & $1-19$ & 88 & 7.0 & 159 & 12.6 & 68 & 5.4 & 315 & 24.9 \\
\hline & $20-39$ & 173 & 13.7 & 182 & 14.4 & 133 & 10.5 & 488 & 38.6 \\
\hline & $40-59$ & 95 & 7.5 & 148 & 11.7 & 84 & 6.7 & 327 & 25.9 \\
\hline & $>59$ & 43 & 3.4 & 56 & 4.4 & 34 & 2.7 & 133 & 10.5 \\
\hline \multirow[t]{2}{*}{ Occupation } & farmer & 231 & 58.0 & 204 & 37.4 & 227 & 71.2 & 662 & 52.4 \\
\hline & other & 168 & 42.0 & 341 & 32.6 & 92 & 28.8 & 601 & 47.6 \\
\hline \multirow[t]{3}{*}{ Birthplace } & ate of Amazonas & 393 & 98.4 & 388 & 71.2 & 316 & 99.1 & 1,097 & 86.8 \\
\hline & other states* & 5 & 1.3 & 87 & 16.0 & 1 & 0.3 & 93 & 7.3 \\
\hline & other regions & 1 & 0.3 & 70 & 12.8 & 2 & 0.6 & 73 & 5.7 \\
\hline \multirow[t]{5}{*}{ Education } & illiterate & 243 & 61.0 & 334 & 61.3 & 212 & 67.0 & 789 & 62.4 \\
\hline & literate & 56 & 14.0 & 92 & 16.9 & 41 & 13.0 & 189 & 14.9 \\
\hline & rimary school & 26 & 7.0 & 44 & 8.1 & 10 & 3.0 & 80 & 6.3 \\
\hline & condary school & 63 & 16.0 & 68 & 12.5 & 53 & 16.0 & 184 & 14.5 \\
\hline & university & 11 & 3.0 & 7 & 1.3 & 3 & 1.0 & 21 & 1.6 \\
\hline \multirow[t]{3}{*}{ Type of housing } & brick & 18 & 4.5 & 22 & 4.0 & 42 & 13.0 & 82 & 6.5 \\
\hline & wood & 375 & 94.0 & 489 & 90.0 & 261 & 82.0 & 1,125 & 89.0 \\
\hline & mixed & 6 & 1.5 & 34 & 6.0 & 16 & 5.0 & 56 & 4.4 \\
\hline \multirow[t]{3}{*}{ Type of roof } & aluminum & 141 & 3.0 & 146 & 27.0 & 222 & 70.0 & 509 & 40.0 \\
\hline & asbestos & 254 & 35.3 & 394 & 72.0 & 95 & 30.0 & 743 & 58.8 \\
\hline & straw/other & 4 & 1.0 & 5 & 1.0 & 2 & 0.5 & 11 & 1.0 \\
\hline \multirow[t]{2}{*}{ Potable water } & yes & 145 & 36.0 & 173 & 32.0 & 254 & 80.0 & 572 & 45.0 \\
\hline & no & 254 & 64.0 & 372 & 68.0 & 65 & 20.0 & 691 & 54.7 \\
\hline \multirow[t]{2}{*}{ Electricity } & yes & 358 & 90.0 & 493 & 90.0 & 281 & 88.0 & 1132 & 89.6 \\
\hline & no & 41 & 10.0 & 52 & 10.0 & 38 & 12.0 & 131 & 10.4 \\
\hline \multirow[t]{2}{*}{ Domestic animals } & yes & 273 & 68.0 & 467 & 86.0 & 242 & 76.0 & 982 & 77.8 \\
\hline & no & 126 & 32.0 & 78 & 14.0 & 77 & 24.0 & 281 & 22.2 \\
\hline \multirow[t]{2}{*}{ Palm trees in yard } & yes & 246 & 62.0 & 456 & 84.0 & 232 & 73.0 & 934 & 73.9 \\
\hline & no & 153 & 38.0 & 89 & 16.0 & 87 & 27.0 & 329 & 26.1 \\
\hline \multirow[t]{2}{*}{ Recognizes kissing bug } & yes & 114 & 29.0 & 143 & 26.0 & 137 & 43.0 & 394 & 31.2 \\
\hline & no & 285 & 71.0 & 402 & 74.0 & 182 & 57.0 & 869 & 68.8 \\
\hline \multirow[t]{2}{*}{ Presence of Didelphis (opossum) } & n) yes & 188 & 47.0 & 382 & 70.0 & 236 & 74.0 & 806 & 64.0 \\
\hline & no & 211 & 53.0 & 163 & 30.0 & 83 & 26.0 & 460 & 36.0 \\
\hline \multirow[t]{2}{*}{ Consumes meat from wild animals } & yes & 294 & 74.0 & 372 & 68.0 & 296 & 93.0 & 962 & 76.1 \\
\hline & no & 105 & 26.0 & 173 & 32.0 & 23 & 7.0 & 301 & 24.0 \\
\hline \multirow[t]{2}{*}{ Consumes fruit from palm trees } & yes & 346 & 87.0 & 445 & 82.0 & 308 & 97.0 & 1,099 & 87.0 \\
\hline & no & 53 & 13.0 & 100 & 18.0 & 11 & 3.0 & 164 & 13.0 \\
\hline
\end{tabular}




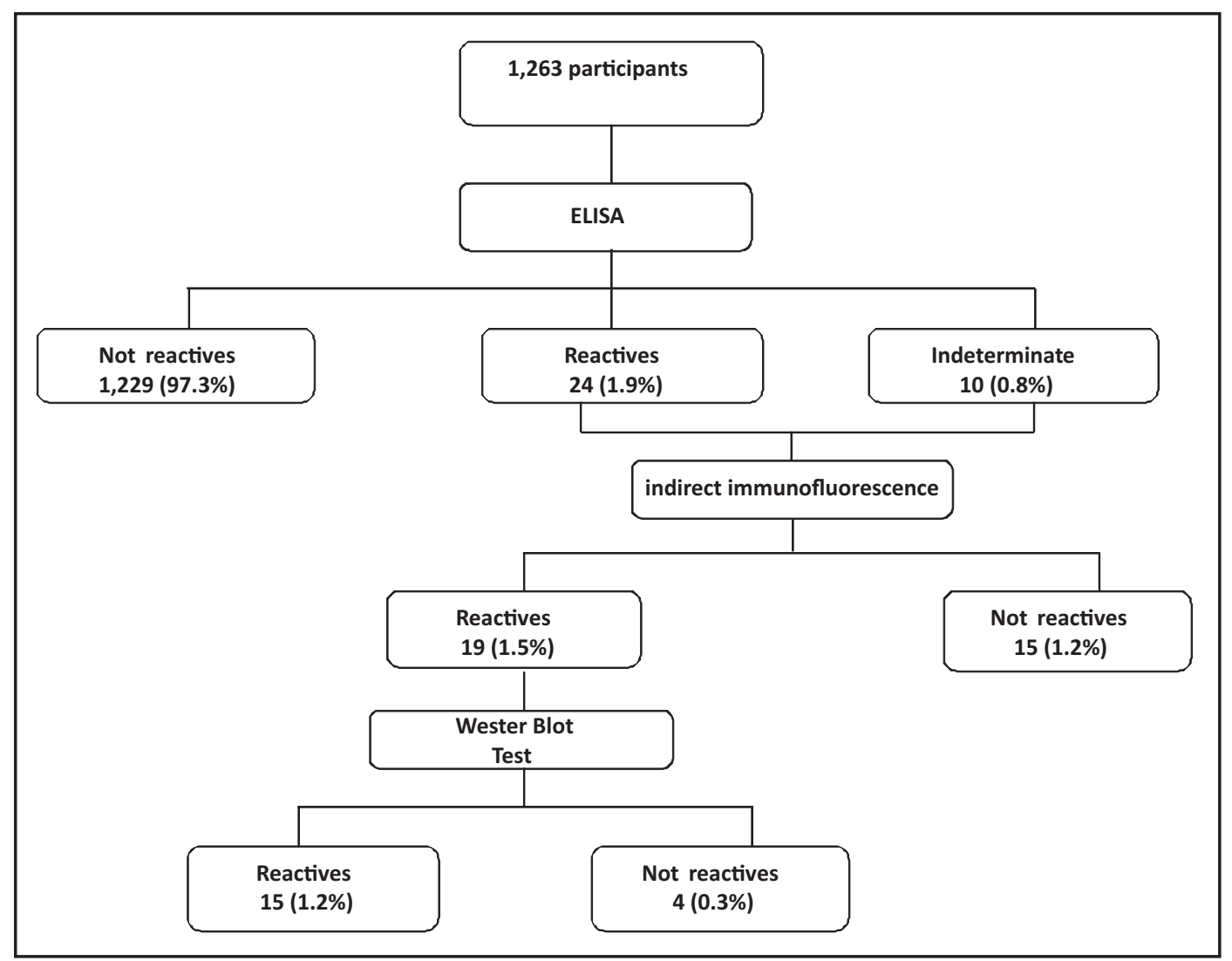

FIGURE 2 - Results of the serological tests of 1,263 samples.

TABLE 2 - Epidemiological characteristics of the seropositive patients in the survey.

\begin{tabular}{lcccccc}
\hline Patients & Municipality & Sex & Age & Education & Occupation & Birthplace \\
\hline $\mathbf{1}$ & Manaus & M & 22 & Literate & Mason & AM \\
\hline $\mathbf{2}$ & Manaus & F & 31 & Primary school & Farmer & AM \\
\hline $\mathbf{3}$ & Manaus & F & 33 & Primary school & Farmer & AM \\
\hline $\mathbf{4}$ & Manaus & M & 47 & Literate & Farmer & AM \\
\hline $\mathbf{6}$ & Manaus & M & 51 & Literate & Farmer & CE \\
\hline $\mathbf{7}$ & Manaus & M & 58 & Literate & Farmer & MG \\
\hline $\mathbf{8}$ & Manaus & M & 85 & Literate & Farmer & AL \\
\hline $\mathbf{9}$ & Coari & M & 83 & Primary school & Farmer & AM \\
\hline $\mathbf{1 0}$ & Coari & M & 57 & Primary school & Public servant & AM \\
\hline $\mathbf{1 1}$ & Tefé & M & 33 & Primary school & Farmer & AM \\
\hline $\mathbf{1 2}$ & Tefé & M & 16 & Literate & Student & AM \\
\hline $\mathbf{1 3}$ & Tefé & M & 50 & Literate & Farmer & AM \\
\hline $\mathbf{1 4}$ & Tefé & M & 55 & Literate & Farmer & AM \\
\hline $\mathbf{1 5}$ & Tefé & M & 59 & Literate & Farmer & AM \\
\hline $\mathbf{M :}$ male; $\mathbf{F}:$ female; AM: Amazonas; CE: Ceará; $\mathbf{M G : ~ M i n a s ~ G e r a i s ; ~ A L : ~ A l a g o a s . ~}$ & & HM \\
\hline
\end{tabular}

agriculturists, and all were literate. There was no family history of CD reported (Table 2).

\section{Clinical evaluation}

All 15 seropositive patients were submitted to clinical examination, electrocardiogram, and echocardiogram. One seropositive patient (non-autochthonous) presented right bundle branch block, anterosuperior hemiblock, and mild left ventricular systolic dysfunction with an ejection fraction of $54 \%$. All the other seropositive patients did not present any cardiologic alterations. No digestive system complaints were reported (Table 2).

\section{DISCUSSION}

The finding of 15 cases reactive for chagasic infection among Amazon rural area inhabitants confirms what the literature has been alerting us to ${ }^{26-28}$ : the emerging Chagas disease outbreak in the area. However, the transmission dynamics of this disease is not known by the majority of the inhabitants of the area, mainly because triatomines (the vectors) are not domiciliated. The fact that these people are aware neither of the disease nor of its transmission forms while living in areas where the prevalent vegetation consists of palm 
trees (the preferred habitat of some triatomine species involved in the Trypanosoma cruzi sylvatic cycle of transmission in Amazonia ${ }^{29-30}$ ) indicates that they are subject to risks of exposure and coexistence with the determining factors for $\mathrm{CD}$ transmission ${ }^{29,31-32}$. For instance, $100 \%$ of the population has electricity in their homes, which are built in areas inside the forest (where the sylvatic cycle occurs). The benefits of electricity might be outweighed by a problem: Light eventually attracts the vectors into their household, causing accidental transmission by hematophagy, defecation, and food contamination $^{2,7,9}$. Occasional incursions of adult triatomines into human dwellings, probably caused by their attraction to light, have been reported ${ }^{8,33}$. In a study carried out in São Paulo de Olivença, state of Amazonas, where the first acute autochthonous CD case in this state was described, Rhodnius robustus, $R$. pictipes (adults and nymphs) were found inside and around dwellings ${ }^{34}$. The feces of triatomines can remain infective for a couple of hours in a highhumidity environment, and food can be accidentally contaminated by secondary carrier insects, such as flies and cockroaches ${ }^{7}$.

Most of the inhabitants reported the consumption of palm tree fruit juices (açai, bacaba, patauá, and buriti) as well as sylvatic animal meat (paca, agouti, and armadillo, among others). Such foods are considered to be a potential source of contamination by T. cruzi, caused by triatomines and their feces or urine infected by metacyclic trypomastigote forms $s^{7,33,35}$. It is noteworthy that these are cultural and subsistence habits of the native population of the Brazilian Amazon, where there have been reports of outbreaks of acute cases supposedly related to oral route transmission caused by the ingestion of $a c ̧ a i$, bacaba, or other juices ${ }^{4,9}$. However, this form of transmission has not been entirely elucidated yet, and the generalized depreciation of these foods may result into severe economic damages as well as the loss of an important source of nutrition in the area. Thus, educational guidance on good hygiene practices in the handling and preparation of these foods before their consumption is critical.

Although the majority of the residents did not recognize the triatomine species that were presented during the visits, $70 \%$ of them reported the presence of the reservoir host, Didelphis marsupialis (opossum), near their dwellings. This situation may facilitate contact between people and the parasite, which may result in the contamination of the inhabitants ${ }^{4,8-9}$ through contact with the anal gland secretions of those animals infected by the metacyclic parasite forms ${ }^{35}$. In the forest areas where this work was accomplished, the presence of the vectors Rhodnius robustus, R. pictipes, and their reservoir host Didelphis marsupialis (naturally infected by $T$. cruzi) near human dwellings was demonstrated ${ }^{36}$. Hence, there is a real possibility of exposure of these inhabitants to contact with the etiological agent and therefore to the infection, as well as the possibility of contamination by marsupials urine $\mathrm{e}^{35}$, reaffirming the potential risk of an endemic disease in Amazonia ${ }^{2-3,10,26-27}$.

The estimated rate of chronic chagasic infection in the population of the studied area reinforces other studies carried out in Amazonia, where the prevalence of chagasic infection varies from $1.9 \%$ to $6.8 \% \%^{5-6,16-17,19,21}$. Although we have registered more cases of $\mathrm{CD}$ in Manaus, the frequency of Chagas disease in Tefé was slightly higher; however, we could not make comparisons because of the difference in the time reference, and the population included in the study in Tefé was numerically smaller than that in Manaus. However, the reported $60 \%$ of patients with CD in the age group above 40 years may indicate old cases with the possibility of progression to symptomatic chronic forms, drawing attention to the importance of diagnosis through the conduct of serological surveys of cases. Such surveys demonstrate the circulation of the disease in municipalities, as has been observed in the municipality of Barcelos, where the disease has already been circulating for some time ${ }^{17}$. We can see that the anti-T. cruzi antibody reaction is cumulative with age, possibly due to longer exposure to the infective agent during the course of a lifetime. The major prevalence in this age range was observed in other studies ${ }^{5-6,16}$. The Serologic National Inquiry (1975 to 1980) indicated a prevalence of $1.88 \%$ in Amazonas ${ }^{19}$. This inquiry estimates a $4.2 \%$ prevalence in the Brazilian population, with higher prevalence rates in the states of Minas Gerais and Rio Grande do Sul $(8.8 \%)^{19}$.

In Barcelos (Rio Negro/AM), a prevalence of 2.8 to $5 \%{ }^{16-17,37}$ has been estimated. The main reasons for these numbers are the subsistence activities of most inhabitants, such as gathering piassava (Leopoldinia piassaba), a palm tree species with high occurrence of the Rhodnius brethesi, a triatomine T. cruzi vector in the area, also known as piassava lice. This disease may also qualify as an occupational disease, as the subjects of the present study reported the identification of and contact with the vectors during their occupational activities. The clinical and electrocardiographic studies carried out in the Amazon region on seropositive cases suggest that the morbidity of this disease in that area is low, possibly due to low parasitemia or to the characteristics of the circulating strains. Nevertheless, the active search for cases has shown the occurrence of hypertrophic cardiomyopathy as well as deaths caused by confirmed chagasic infection ${ }^{38-39}$.

One of the 15 seropositive patients presented cardiologic alterations indicative of chronic chagasic infection, such as right bundle branch block, anterosuperior hemiblock, and mild left ventricular systolic dysfunction with an ejection fraction of 54\%. These conditions may also be related to an arterial hypertension history as well as aging; in such cases, it is impossible to assure that these findings are related to $\mathrm{CD}$. However, the systolic dysfunction (FE: 54\%) detected by the echocardiogram and the right bundle branch block are conditions often observed in chronic chagasic cardiopathy patients ${ }^{24-25,40-41}$

In the other 14 cases, despite the lack of cardiologic or digestive manifestations, the patients were advised about the necessity of an annual clinical checkup comprising specific tests and further evaluations.

Based on the present study, it is not clear by what means the transmission dynamics occurs in that area. It is also unknown how the patients were infected and if such infection was related to their work because, as they have attested, they perform gathering activities and/or stay in the forest areas for great periods of time and/or live in rural areas and/or consume palm tree fruit juice and sylvatic animal meat. All these habits introduce these people into the presumable cycle of transmission of chagasic infection in the Amazon region ${ }^{2,4,8,26-28,31-33}$. It is noteworthy that out of the 15 identified cases of chagasic infection, three originated from endemic areas (states of Minas Gerais, Ceará, and Alagoas). This fact reinforces the evidence of the risks of the movement of $\mathrm{CD}$ cases in the Brazilian Amazonia being caused by human migrations from endemic areas to Amazonia due to the increasing proximity between the vectors, the trypanosome reservoir hosts and people ${ }^{10-11,26-27}$.

Chagas disease is an emerging public health problem and an evolving anthropozoonosis arising from T. cruzi infection of vectors and sylvatic animals ${ }^{2,48,826-28,37}$. The results of this study ratify the importance of monitoring CD cases in Amazonia, particularly in the state of Amazonas. 


\section{ACKNOWLEDGMENTS}

The authors would like to thank Elcimar Neves Cavalcante, Maria Rita Teixeira Almeida, and all the people who were indispensable in patient identification and in the collection and storage of samples. We also thank the Secretaria Municipal de Saúde de Coari, Prefeitura Municipal de Tefé, for the critical support in developing this study.

\section{CONFLICT OF INTEREST}

The authors declare that there is no conflict of interest.

\section{FINANCIAL SUPPORT}

Conselho Nacional de Pesquisas (CNPq) and Fundação de Amparo a Pesquisa do Estado do Amazonas (FAPEAM).

\section{REFERENCES}

1. Shaw J, Lainson R, Fraiha H. Epidemiology of the first autochthonous cases of Chagas' disease recorded in Belem, Para, Brazil. Rev Saúde Pública 1969; 3:153-157.

2. Valente SAS, Valente VC, Fraiha-Neto H. Considerações sobre a epidemiologia e transmissão da doença de Chagas na Amazônia Brasileira. Mem Inst Oswaldo Cruz 1999; 94(suppl I):395-398.

3. Coura JR, Junqueira ACV, Fernandes O, Valente SA, Miles MA. Emerging Chagas disease in Amazonian Brazil. Trends Parasitol 2002;18:171-176.

4. Pinto AY, Valente SA, Valente VC, Junior AGF, Coura JR. Acute phase of Chagas disease in the Brazilian Amazon region: study of 233 cases from Para, Amapa and Maranhão observed between 1988 and 2005. Rev Soc Bras Med Trop 2008; 41:602-614.

5. Dantas-Maia TO, Castro C, Luquetti AO, Macêdo V. Seroprevalence of American trypanosomiasis in adults in an area of the western Brazilian Amazon region. Rev Soc Bras Med Trop 2007; 40:436-442.

6. Boia MN, Motta LP, Salazar MD, Mutis MP, Coutinho RB, Coura JR. Crosssectional study of intestinal parasites and Chagas' disease in the Municipality of Novo Airão, State of Amazonas, Brazil. Cad Saude Publica 1999;15:497-504.

7. Dias JCP. Notes about of Trypanosoma cruzi and yours bio-ecology characteristics with agents of the transmission by meals. Rev Soc Bras Med Trop 2006; 39:370-375.

8. Coura JR, Junqueira ACV, Boia MN, Fernandes O. Chagas disease: from bush to huts and houses. Is it the case of the Brazilian Amazon? Mem Inst Oswaldo Cruz 1999; 94 (suppl 1):379-384.

9. Teixeira AR, Monteiro PS, Rebelo JM, Arganaraz ER, Vieira D, Lauria-Pires L, et al. Emerging Chagas disease: trophic network and cycle of transmission of Trypanosoma cruzi from palm trees in the Amazon. Emerg Infect Dis 2001; $7: 100-112$.

10. Dias JCP, Prata A, Schofield CJ. Chagas' disease in the Amazon: an overview of the current situation and perspectives for prevention. Rev Soc Bras Med Trop 2002; 35:669-678

11. Silveira AC. Epidemiological and social determinants of Chagas disease and its control in the Amazon countries - group discussion. Mem Inst Oswaldo Cruz 2007; 102 (suppl 1):71-74.

12. Ferraroni JJ, Nunes de Melo JL, Camargo ME. Moléstia de Chagas na Amazônia. Ocorrência de seis casos suspeitos, autóctones, sorologicamente positivos. Acta Amazônica 1977; 10:759-762.

13. França MS, Frade JM, Konazugawa K, Almeida FB. Doença de Chagas: primeiro caso autóctone na Amazônia Ocidental, Amazonas, Brasil. Acta Amazônica 1980; 10:759-762.

14. Matta A. Um novo reduvídeo do Amazonas. Rhodnius brethesi n.sp. Amazonas Med (Manaus) 1919; 2:93-94.

15. Almeida FB. Triatomíneos da Amazônia. Encontro de três espécies naturalmente infectadas por Trypanosoma semelhante ao cruzi, no Estado do Amazonas (Hemíptera, Reduviidae). Acta Amazônica 1971; 1:83-89.

16. Coura JR, Junqueira ACV, Boia MN, Fernandes O, Bonfante C, Campos JE, et al. Chagas disease in the Brazilian Amazon: IV. a new cross-sectional study. Rev Inst Med Trop São Paulo 2002; 44:159-165.
17. Brum-Soares LM, Xavier SS, Sousa AS, Borges-Pereira J, Ferreira JMBB, Costa IR, et al. Morbidade da doença de Chagas em pacientes autóctones da microrregião do Rio Negro, Estado do Amazonas. Rev Soc Bras Med Trop 2010; 43:170-177.

18. Medeiros MB, Guerra JA, Lacerda MV. Meningoencephalitis in a patient with acute Chagas disease in the Brazilian Amazon. Rev Soc Bras Med Trop 2008; 41:520-521.

19. Camargo ME, Silva GR, Castilho EA, Silveira AC. Serological survey of the prevalence of Chagas' infection in Brazil, 1975/1980. Rev Inst Med Trop São Paulo 1984; 26:192-204.

20. Monteiro WM, Barbosa MGV, Toledo MJO, Fé FA, Fé NF. Série de casos agudos de doença de Chagas atendidos num serviço terciário de Manaus, Estado do Amazonas, de 1980 a 2006. Rev Soc Bras Med Trop 2010; 43:207-210.

21. Voller A, Bartlett A, Bidwell E. Enzyme imunoassays with especial reference to ELISA techniques. J Clin Patol 1978; 31:507-520.

22. Umezawa ES, Nascimento MS, Kesper NJ, Coura JR, Borges-Pereira J, Junqueira $\mathrm{ACV}$, et al. Immunoblot assay using excreted-secreted antigens of Trypanosoma cruzi in serodiagnosis of congenital, acute, and chronic Chagas' disease. J Clin Microbiol 1996; 34:2143-2147.

23. Amato-Neto V, Marchi CR, Ferreira CS, Ferreira AW. Observations on the use of TESA blot for the serological diagnosis of Chagas' disease. Rev Soc Bras Med Trop 2005; 38:534-535.

24. Macêdo V, Prata A, Silva GR. Prevalência de alterações eletrocardiográficas em chagásicos. Arq Bras Cardiol 1982; 38:261-564.

25. Prata A. Clinical and epidemiological aspects of Chagas disease. Lancet Infect Dis 2001 ; $1: 92-100$

26. Coura JR. Chagas' disease as endemic to the Brazilian Amazon: risk or hypothesis? Rev Soc Bras Med Trop 1990; 23:67-70.

27. Dias JCP, Prata A, Correia D. Problems and perspectives for Chagas disease control: in search of a realistic analysis. Rev Soc Bras Med Trop 2008; 41:193-196.

28. Relatório Técnico. 2a Reunião da Iniciativa Intergovernamental de Vigilância e Prevenção da Doença de Chagas na Amazônia. Rev Soc Bras Med Trop 2006; 39:311-317.

29. Abad-Franch F, Palomeque FS, Aguilar HM, Miles MA. Field ecology of sylvatic Rhodnius populations (Heteroptera, Triatominae): risk factors for palm tree infestation in western Ecuador. Trop Med Int Health 2005;10:1258-1266.

30. Mascarenhas BM. Triatomíneos da Amazônia: sobre o habitat e algumas considerações comportamentais de Rhodnius brethesi Matta, 1919 (Hemiptera, Reduviidae: Triatominae) na Região do Médio Rio Negro, Amazonas. Bol Mus Para Emilio Goeldi Serv Zool 1991; 7:107-116.

31. Silveira AC, Passos ADC. Altos índices de prevalência sorológica de infecção chagásica em área da Amazônia. Rev Soc Bras Med Trop 1986; 19 (suppl 1): 45.

32. Briceño-León R. Chagas disease and globalization of the Amazon. Cad Saude Publica 2007; 23 (suppl 1):33-40.

33. Junqueira ACV, Albajar PV, Coura JR. Doença de Chagas na Amazônia Brasileira. In: Coura JR, editor. Dinâmica das doenças infecciosas e parasitárias. Rio de Janeiro: Guanabara Koogan; 2005. p. 595-601.

34. Fé NF, França MS, Carvalho-Costa FA. Reassessing the entomlogic investigation around the first authochthonous case of Chagas disease in Western Brazillian Amazon. Mem Inst Oswaldo Cruz 2009; 104:121-123.

35. Deane LM. Tripanosomídeos de mamíferos da Região Amazônica IV Hemoscopia e xenodiagnóstico de animais silvestres da Estrada Belém-Brasília. Rev Inst Med Trop São Paulo 1976; 9:143-148.

36. Magalhães LKC, Preste SR, FéNF, Ciriano CM, Fé FAA, Fabiano MP, et al. Infecção natural e diversidade de espécies de vetores da doença de Chagas nos municípios de Manaus, Coari e Tefé/AM. Rev Soc Bras Med Trop 2009; 42 (supll I):448.

37. Coura JR, Junqueira ACV, Giordano CM, Funatsu RK. Chagas' disease in the Brazilian Amazon. I-Ashort review. Rev Inst Med Trop São Paulo 1994; 36:363-368.

38. Albajar PV,Laredo SV, Terrazas MB, Coura JR. Dilated cardiomyopathy in patients with chronic chagasic infection: report of two fatal autochthonous cases from Rio Negro, State of Amazonas, Brazil. Rev Soc Bras Med Trop 2003; 36:401-407.

39. Xavier SS, Sousa AS, Albajar PV, Junqueira ACV, Boia MN, Coura JR. Chronic chagasic cardiopathy in the Rio Negro, Amazon State. Report of three new autochthonous cases confirmed by serology, clinical examination, chest X-rays, electro and echocardiography. Rev Soc Bras Med Trop 2006; 39:211-216.

40. Castro C, Prata A, Macêdo V. A 13-year clinical study on 190 chronic chagasic patients from Mambaí, Goiás, Brazil. Rev Soc Bras Med Trop 2001; 34:309-318.

41. Borges-Pereira J, Xavier SS, Pirmez C, Coura JR. Chagas disease in Virgem da Lapa, Minas Gerais, Brazil. IV. Clinical and epidemiological aspects of left ventricular aneurism. Rev Soc Bras Med Trop 1998; 31:457-463. 